Int. J. Odontostomat.,

6(3):323-326, 2012.

\title{
Rehabilitation of Fractured Tooth by a Custom Made Fibre Reinforced Composite Post
}

\author{
Rehabilitación del Diente Fracturado por un Poste de Resina Reforzado con Fibra
}

\author{
Lora Mishra*; Manoj Kumar $^{* *}$ \& Nishant ${ }^{* * *}$
}

MISHRA, L.; KUMAR, M. \& NISHANT. Rehabilitation of fractured tooth by a custom made Fibre reinforced composite post. Int. J. Odontostomat., 6(3):323-326, 2012.

ABSTRACT: Management of traumatic injuries to the teeth is a challenge to the practising dentist. It has no prescriptive method for occurring, possesses no significant predictable pattern of intensity or extensiveness and occurring at times when dentists are least prepared for it. Ninety-two percent of traumatic injuries results in fracture of maxillary permanent central incisors because its protrusive and anterior positioning. The young permanent maxillary central incisor root canal chamber is large and tapered. This case report describes the management of Ellis Class III fractured tooth in a young permanent maxillary central incisor by an innovative clinical procedure.

KEY WORDS: tooth fracture, composite resin, dental pulp cavity.

\section{INTRODUCTION}

Various international studies it has been reported that males experiences more dental trauma as compared to females (Stockwell, 1988; Kania et al., 1996). The prevalence of traumatic dental injuries varies from 13.8-15.1\% (Gupta et al., 2002; Ravishankar et al., 2010). The most common cause for traumatic dental injury is falls and collision (Ravishankar et al.; Mallikaew et al., 2006; Marcenes \& Murray, 2001; Nicolau et al., 2001). The maxillary central incisors are the most common teeth affected during trauma (Bastone et al., 2000). Some articles have reported that $25 \%$ of patient population under 18 years old, sustained dental injuries in the form of crown fractures in maxillary incisors (Andreasen \& Ravn, 1972; Petti \& Tarsitani, 1996). Subsequently, anterior crown fractures lead to discomfort and serious psychological, aesthetic, functional and phonetic problems that can affect social relationship (Traebert et al., 2003; Marcenes et al., 1999). This article highlights the management of Ellis Class III fracture in young permanent maxillary central incisors with custom made FRC post.

\section{CASE REPORT}

An 18 year old boy reported to the Department of Conservative and Endodontics with fracture of upper central incisors (Fig. 1). He had history of trauma due toaccident 5 days prior to reporting to our department. On examination 11 and 21 had Ellis Class II fracture and was non-mobile. Intra oral periapical radiograph reveled fracture line involving enamel, dentine and approximating pulp (Fig. 2). Patient was advised antiinflammatory drugs and was asked to report after a month. After a month when patient reported, on examination there was no colour change but tooth was having continuous dull pain that was severely tender on percussion. Thermal test and Electric pulp test reveled abnormal response.

Methodology. Access cavity was prepared with endo access bur size 3 (Densply) and working length was determined using apex locator (Densply, X smart Duo) and confirmed by IOPAR. The canal was constantly irrigated with $3 \%$ sodium hypochlorite, saline and $17 \%$ EDTA solution. The canal was dried using paper points and intra canal medicament was placed for a week.

\footnotetext{
Department of Conservative Dentistry and Endodontics, Institute of Dental Sciences,S 'O' A University, K-8, Ghatikia, Kalinga Nagar, Bhubaneswar, India.

* Department of Peridontia, Institute of Dental Sciences,S 'O' A University, K-8, Ghatikia, Kalinga Nagar, Bhubaneswar, India.

${ }^{* * *}$ Consulting Endodontist, Pune, India.
} 


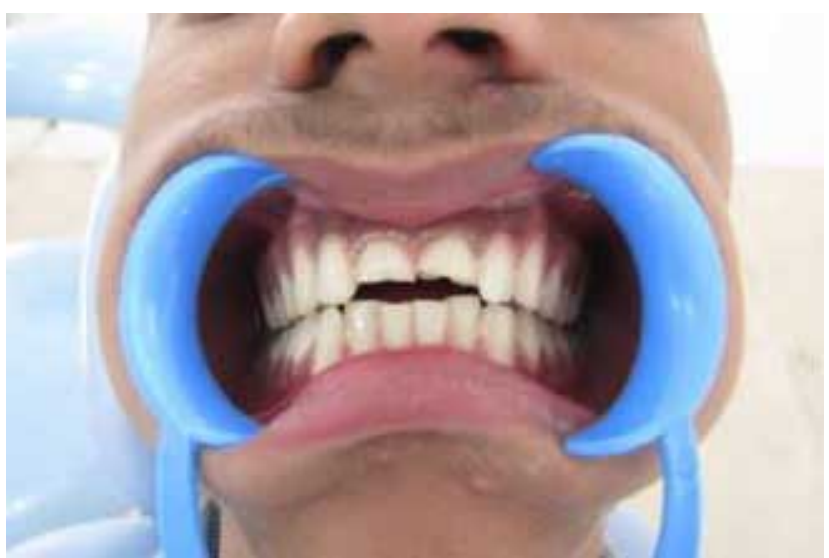

Fig. 1. Ellis Class II fracture of 11 and 21.

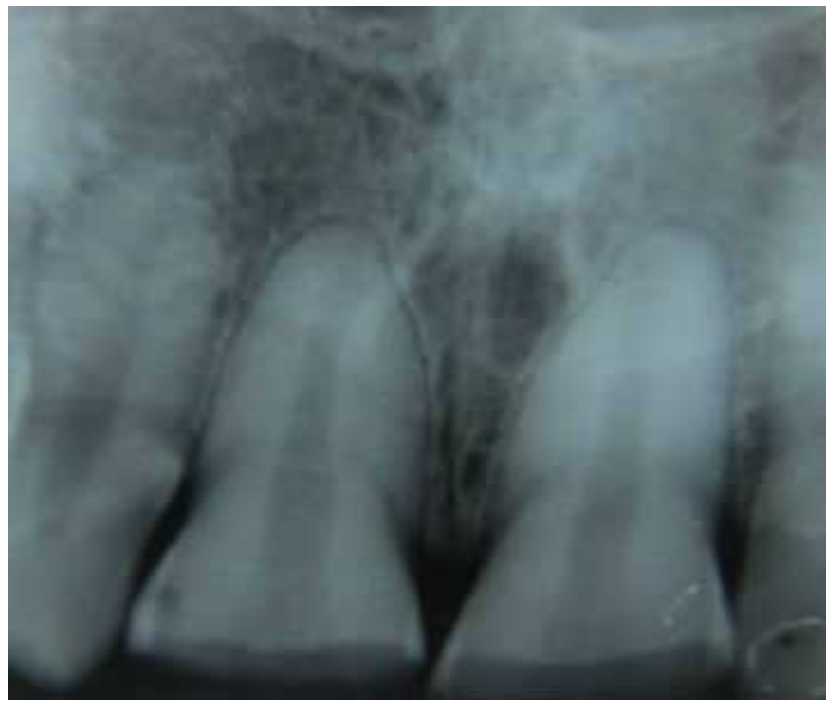

Fig. 2. IOPAR of 11 and 21 region.

After one week temporary access cavity restoration as removed and initial file binding to apical constriction was $25 \mathrm{~K}$ file (MANI manufacturing) .the apical constriction as enlarged till $40 \mathrm{~K}$ file (MANI).

Step back preparation was done with regular recapitulation and irrigation. The canal was finally shaped with $M$ two basic sequence and advance sequencing. The canal was sectional obturated with Guttapercha coated with AH plus sealer (DENSPLY).

The department had Tenax Fibre Trans Esthetic tapered post of size $1.1 \mathrm{~mm}$ (Fig. 3). This size fiber post was loosely bound to the tapered anatomy of root canal of both the incisors.

This FRC post was reinforced with the Braided fibers (INTERLIG). The entire post was then etched with $37 \%$ phosphoric acid for 30 seconds and then

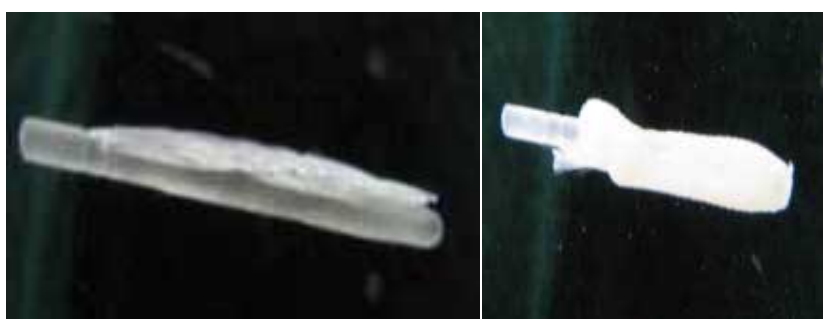

Fig. 3. adaptation of Fibers and composite after acid etching and application of bonding agent on FRC post.

washed dried with three-way syringe. Bonding agent (3M ESPE, Single Bond) was applied with micro tip brush and cured for 40 seconds on each side. The composite (Filtek, 3M ESPE) was adapted on to the post and just like during custom made post the entire unit was taken and inserted into the root canal (Fig. 4). Then it was retrieved immediately and cured for 40 seconds all around. The post dimensions were adjusted by yellow ring finishing bur.
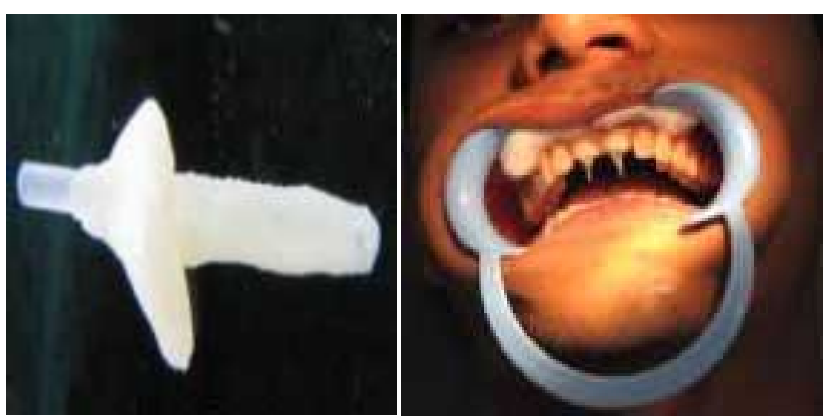

Fig. 4. Composite adapted on FRC post takes the shape of root canal when inserted into it.

The canal was acid etched using micro brush. Bonding agent was applied and excess was removed using paper point. The custom made FRCpost was silanized using silanating agent. Then it was luted into the canal using resin-based sealer (Multilink, IVOCLAR) (Fig. 5).

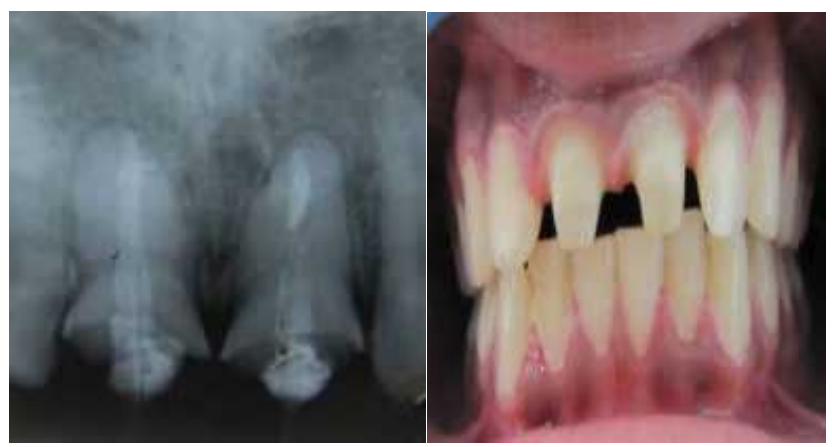

Fig. 5. The IOPAR revels luting of FRC post and Core build up done with composite. 
The coronal restoration with composite was done and after tooth preparation the impression of teeth with rubber based impression material taken. The temporary crown was placed using Zinc Oxide Eugenol sealer.and patient was recalled after a week for luting of Full Ceramic Crown (Fig. 6).

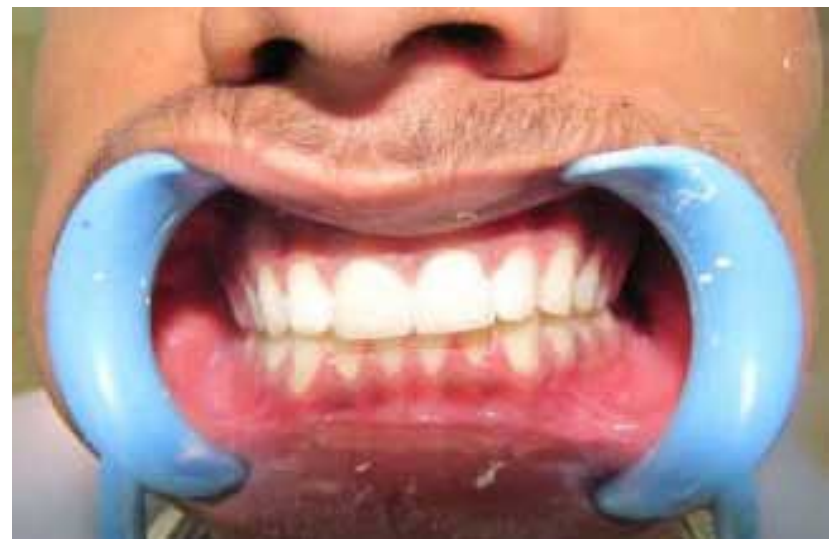

Fig. 6. Full ceramic crown cementation.

\section{DISCUSSION}

The traumatic dental injury increases bacterial potential to invade sectioned dentinal tubules and therefore produce acute inflammation and pulp (Díaz, 2008). Young permanent tooth has a rich vascular supply and therefore has high potential of healing. Pulp vitality testing should be carried out on traumatized teeth over an extended period to monitor their vitality following the traumatic incident, as teeth which may initially not respond to testing may well do so after a period of months (Pitt Ford \& Patel, 2004). Therefore patient was asked to report after a month for vitality test and to initiate endodontic treatment.

Restoration of endodontically treated teeth is a complicated procedure because of the various factors that need to be considered. These factors include retention of the restoration, the amount of remaining sound tooth structure, masticatory forces, prevention of microleakage and also the aesthetic performance in the case of anterior teeth.

It is critical to establish a minimal circumferential ferrule of $1.5 \mathrm{~mm}$. This effect requires approximately 4.5 $\mathrm{mm}$ of tooth structure above the osseous crest: $1.5 \mathrm{~mm}$ for the ferrule and $3.0 \mathrm{~mm}$ of biologic width. Failure to heed this guideline reduces the prognosis and longevity of the restoration (Lenchner \& Lenchner, 1989). Since patient did not want his esthetics to be compromised at any cost and fractured tooth was closed to mesial gingival margin, post and core was indicated.

The traditional custom-cast dowel core provides a better geometric adaptation to excessively flared or elliptical canals, and almost always requires minimum tooth structure removal (Smith et al., 1998). Custom cast post-and-cores adapt well to canals with extremely tapered canals or those with a noncircular cross section and/or irregular shape, and roots with minimal remaining coronal tooth structure. This technique incorporates the advantages of both FRC post and custom-made post.

FRC posts were introduced as an aesthetic alternative; their use is based on the mechanical notion that materials restoring endodontically treated teeth should have similar mechanical properties with that of tooth substance (Asmussen et al., 1999). Composite posts possess an elastic modulus close to that of dentin, thus creating a more homogenous restorative system consisting of the post, resin cement, core material along with the tooth substance. In this way, distribution of stresses to the root is more even and there is less risk of a root fracture (Dean et al., 1998).

Braided or woven fibers, which can resist multi directional forces, are good choice for chair side reinforcement-restorative technique. The fiber reinforces the post and composite that was added to it.

For optimal retention, between one half and two thirds of the post should be anchored into an osseoussupported root. This requires the preparation of a space in the root canal system to anchor the post. Unfortunately, the preparation of a root canal space to fit a prefabricated post with the manufacturer's specific post drill has become generally accepted. In this case deliberately a small sized post was selected and was modified to adapt the canal anatomy with minimal preparation of the root space.

Weine (1996) has stated that more endodontically treated teeth are lost due to improper restoration than to endodontic failure.

This technique allows immediate core build up with composite, reduces the number of appointment and minimal laboratory procedures.

In conclusion, the use of skills, knowledge of the material and adequate ferrule effect, should yield a quantum leap in the long-term success of post endodontic and restorative care of fractured tooth in a young permanent dentition. 
MISHRA, L.; KUMAR, M. \& NISHANT. Rehabilitación del diente fracturado por un poste de resina reforzado con fibra. Int. J. Odontostomat., 6(3):323-326, 2012.

RESUMEN: El tratamiento de lesiones traumáticas de los dientes son un reto para el dentista. No tiene un método prescriptivo de ocurrencia, no posee ningún patrón predecible significativo de la intensidad o amplitud y se producen en momentos en que los dentistas están menos preparados para ello. El $92 \%$ de las lesiones traumáticas resultan en la fractura de incisivos centrales permanentes debido a su posición anterior y protrusiva. La cámara pulpar del canal radicular en el incisivo central superior permanente joven es grande y cónica. Este caso describe el manejo de un diente incisivo central superior permanente joven con fractura Ellis Clase III mediante un procedimiento clínico innovador.

PALABRAS CLAVE: fractura dentaria, resina compuesta, cavidad pulpar dentaria.

\section{REFERENCES}

Andreasen, J. O. \& Ravn, J. J. Epidemiology of traumatic dental injuries to primary and permanent teeth in a Danish population sample. Int. J. Oral Surg., 1(5):235-9, 1972.

Asmussen, E.; Peutzfeldt, A. \& Heitmann, T. Stiffness, elastic limit, and strength of newer types of endodontic posts. $J$. Dent., 27(4):275-8, 1999.

Bastone, E. B.; Freer, T. J. \& McNamara, J. R. Epidemiology of dental trauma: a review of the literature. Aust. Dent. J., 45(1):2-9, 2000.

Dean, J. P.; Jeansonne, B. G. \& Sarkar, N. In vitro evaluation of a carbon fiber post. J. Endod., 24(12):807-10, 1998.

Díaz, J. A. Crown fractures in upper maxillary central incisors; 24 months follow-up and clinical outcome in Children. Int. J. Odontostomat., 2(1):83-94, 2008.

Gupta, K.; Tandon, S. \& Prabu, D. Traumatic injuries to incisor in children of South Kanara District- A prevalence study. J. Indian Soc. Pedod. Prev. Dent., 20(3):107-13, 2002.

Kania, M. J.; Keeling, S. D.; McGorray, S. P.; Wheeler, T. T. \& King, G. J. K. Risk factors associated with incisor injury in elementary school children. Angle Orthod., 66(6):423-32, 1996.

Lenchner, N. H. \& Lenchner, M. Biologic contours of teeth: Therapeutic contours of restorations, Part II. Pract. Periodont. Aesthet. Dent., 1(5):18-21, 1989.

Mallikaew, P.; Watt, R. G. \& Sheiham, A. Prevelance and factors associated with traumatic dental injuries to anterior tooth of 11-13yrs old thai children. Community Dent. Health, 23(4):222-7, 2006.

Marcenes, W.; al Beiruti, N.; Tayfour, D. \& Issa, S. Epidemiology of traumatic dental injuries to permanent incisors of school children aged 9-12 in Damascus, Syria. Endod. Dent. Traumatol., 15(3):117- 23, 1999.

Marcenes, W. \& Murray, S. Social deprivation and traumatic dental injuries among 14years old school children in
Newham, London. Dent. Traumatol., 17(1):17-21, 2001.

Nicolau, B.; Marcenes, W. \& Sheiham, A. Prevalence, causes and correlates of traumatic dental injuries among 13-yearolds in Brazil. Dent. Traumatol., 17(5):213-7, 2001.

Petti, S. \& Tarsitani, G. Traumatic injuries to anterior teeth in Italian school children:prevalence and risk factors. Endod. Dent. Traumatol., 12(6):294-7, 1996.

Pitt Ford, T. R. \& Patel, S. Technical equipment for assessment of dental pulp status. Endod. Top., 7(1):2-13, 2004.

Ravishankar, T. L.; Kumar, M. A.; Ramesh, N. \& Chaitra, T. R. Prevalence of traumatic dental injuries to permanent incisors among 12-year-old school children in Davangere, South India. Chin. J. Dent. Res., 13(1):57-60, 2010.

Smith, C. T.; Schuman, N. J. \& Wasson, W. Biomechanical criteria for evaluating prefabricated post-and-core systems: a guide for the restorative dentist. Quintessence Int., 29(5):305-12, 1998.

Stockwell, A. J. Incidence of dental trauma in the Western Australian School Dental Service. Community Dent. Oral Epidemiol., 16(5):294-8, 1988.

Traebert, J.; Peres, M. A.; Blank, V.; Böell, R.da S. \& Pietruza, J. A. Prevalence of traumatic dental injury and associated factors among 12-year-old school children in Florianopolis, Brazil. Dent. Traumatol., 19(1):15-8, 2003.

Wein, F. S. Endodontic Therapy. $5^{\text {th }}$ Ed. St. Louis, Mosby, 1996.

Correspondence to:

Dr. Lora Mishra

Sr. Lecture, Department of Conservative Dentistry and Endodontics

Institute of Dental Sciences, S 'O' A University

K-8, Ghatikia, Kalinga Nagar, Bhubaneswar, Orissa-751003 INDIA

Email : loraprankster@yahoo.co.in

Received: 13-06-2012

Accepted: 09-08-2012 